\title{
A Christmas tree market analysis: implications from Alberta, Canada data
}

\author{
by P.M. Woodard ${ }^{1}$, D. Needham ${ }^{2}$, W.E. Phillips ${ }^{2}$ and L.F. Constantino ${ }^{2}$
}

The 1990 Christmas tree market in Alberta, Canada was assessed in an attempt to determine the feasibility of growing such trees for local consumption. Almost 5500 questionnaires were delivered to households and commercial establishments as part of this survey. In addition, many personal interviews were conducted. The information presented pertains to the wholesale and retail sales volumes and values by tree species. The socio-economic background of tree buying consumers and their traditional celebration and purchasing habits are also included. Our results suggest Albertans spent over $\$ 7$ million (retail) to buy 300,000 natural Christmas trees during the 1990 holiday season, and that $87 \%$ of the wholesale value or $\$ 2.6$ million was spent to buy trees from outside of Alberta. Consumers would prefer to buy highquality, locally-grown trees.
Le marché des arbres de Noël de 1990 en Alberta, Canada, a été évalué pour tenter de déterminer la possibilité de faire pousser de tels arbres pour consommation locale. Près de 5500 questionnaires ont été distribués dans des résidences et des établissements commerciaux au cours de ce sondage. De plus plusieurs entrevues personnelles ont été faites. L'information recueillie a trait aux volumes de vente en gros et au détail et à la valeur de ces ventes par espèces d'arbres. L'environnement socio-économique des acheteurs d'arbres ainsi que leur façon traditionnelle de célébrer et leurs habitudes d'achats sont également introduits. Nos résultats démontrent que les Albertains ont déboursé plus de 7 millions de dollars (vente au détail) pour acheter 300000 arbres naturels de Noël au cours de la période des Fêtes de 1990, et que $87 \%$ de la valeur des ventes en gros, soit 2.6 millions de dollars, a été déboursée à l'extérieur de l'Alberta. Les consommateurs préféreraient acheter des arbres de grande qualité, produits localement.

\section{Introduction}

The natural Christmas tree industry is an important source of revenue for many Canadian producers. In 1992, D. Chernushenko reported "Canada's growers sell more than three million Christmas trees annually, generating retail sales of \$55-million" ". The continued success in marketing Christmas trees is highly dependent on knowing what people want and having the ability to fulfill these expectations with competitively priced products.

Previous marketing studies have identified the types of Christmas trees preferred and the demographic characteristics of the purchasers. Hildebrandt (1991) provided a good discussion of the market forces in the United States with specific reference to the situation in Kansas. In Canada, recent reports by Anaka (1990) clearly described this market in British Columbia, while Winsor (1990) described the marketing condition in and around St. John's, Newfoundland. The goal of this study is to describe the demand side of this market for the Province of Alberta. Specifically, to determine: (1) the size of this Christmas tree market in Alberta to include sales volumes and values for natural and artificial trees, which were purchased for home or commercial use, (2) the degree of substitution between these two

${ }^{1}$ Author to whom all correspondence should be addressed. Department of Forest Science, University of Alberta, 751 General Services Building, Edmonton, Alberta, Canada T6G 2H1.

${ }^{2}$ Department of Rural Economy, University of Alberta, Edmonton, Alberta, Canada.

3Toronto Globe and Mail (newspaper) Friday, December 11, 1992. All dollar amounts in this report are in 1990 Canadian unless otherwise noted. product types especially with respect to market trends, consumer preferences, volumes and prices, (3) the socio-economic background of tree buying consumers (income class, education, family size, age class, dwelling type), and (4) the characteristics of the trees preferred (live versus cut trees, to include size, species, and shape). In addition, we identified the main sources of trees in Alberta and how these trees were marketed.

Questionnaires were mailed to 5,100 Alberta households in early December 1990 . Of these, 4,974 were delivered. A total of 488 questionnaires were mailed to commercial establishments because according to Compusearch Corporation's 'FAR Online' data base service there is approximately one such entity for every ten households in Alberta. The sample population was randomly selected from telephone directories (Needham et al. 1991). Over $27 \%$ of the household, and $37.5 \%$ of the commercial questionnaires, were returned. Also as part of this study, we personally interviewed retailers using a standardized form. There were three reasons for interviewing the Christmas tree retailers: (1) to determine the structure of this industry, (2) to identify the costs associated with retailing trees and (3) to determine the size of this market in Alberta relative to species purchased, volume of sales and prices. Lastly, we solicited price lists by mail from 11 wholesalers, who were known to be shipping trees to Alberta in an attempt to verify the wholesale price information provided by the retailers.

\section{Results}

\section{(a) Household Consumers}

The majority of the household respondents (72\%) reside in a detached house. Over $93 \%$ of the respondents had complet- 
ed grade 12 , yet on average, they have just over 8 years of formal education and 2.6 years of post secondary education. Almost $20 \%$ had at least one family member aged 6 years or less; $30 \%$ had at least one family member aged 12 years or less and $41 \%$ have at least one family member 18 years or less. Just over $20 \%$ of the households had a combined income of between $\$ 50,000$ to $\$ 69,000$ and over $76 \%$ had a combined income of between $\$ 30,000$ and $\$ 99,000$.

Most households celebrate holiday season by "having a Christmas tree" (85\%), "giving gifts" (95\%), "having a special meal or baking" $(88 \%)$, "sending cards" $(84 \%)$ and "hanging stockings" (61\%). Many people also indicated they "took part in outdoor activities" (28\%), "visited family" (41\%), "socialized" (24\%) and "took part in church related activities" (19\%). Most households also displayed a wreath (or wreaths), which were most often artificial $(66 \%)$. The average price paid for the wreath was $\$ 12.08$ in 1990 dollars.

Over $85 \%$ of the households surveyed in Alberta displayed a Christmas tree during the 1990 holiday season. Of these, $50 \%$ displayed a natural tree only, $4 \%$ displayed both natural and artificial tree and $46 \%$ displayed an artificial tree only. These results are compared to those of previous studies in Table 1. The reasons for not displaying a tree were: "away at Christmas" $(47 \%)$, "no children in household" (29\%), "too much trouble" (27\%), "home too small" (24\%), "too expensive" (15\%) and "environmental reasons" $(13 \%)^{4}$. Yet of the respondents who did not display a tree during the 1992 Christmas season, more than half said they planned on displaying a tree in the future, and of these $67 \%$ said they would display a natural tree. In general, money was not a factor in why people chose natural trees.

The reasons for choosing an artificial tree (listed in order of frequency) are: (1) "less mess", (2) "no need to shop every year", (3) "safety concerns", (4) "ease of setting up the tree", (5) "cost considerations", (6) "environmental concerns", (7) "personal preference" and (8) "size considerations". Over $72 \%$ of these respondents had displayed a natural tree but switched for the

\begin{tabular}{|c|c|c|c|c|c|}
\hline Survey & State/Province & Natural & $\begin{array}{r}\text { Artificial } \\
(\%)\end{array}$ & Both & No tree \\
\hline $\begin{array}{l}\text { Brummel (1965) } \\
\text { Hildebrandt et al. }\end{array}$ & Kansas & $34-43$ & $19-34$ & $\mathrm{NR}^{1}$ & $36-46$ \\
\hline (1989) & Kansas & 34 & 46 & 2 & 18 \\
\hline $\begin{array}{l}\text { Gwinner (1987) } \\
\text { Hu and Burns }\end{array}$ & Indiana & 30 & 54 & NR & 16 \\
\hline $\begin{array}{l}\text { (1981) } \\
\text { Chafin (1988) }\end{array}$ & $\begin{array}{l}\text { Louisiana } \\
\text { Southwest }\end{array}$ & 41 & 37 & NR & 22 \\
\hline & Ohio & 23 & 59 & NR & 18 \\
\hline $\begin{array}{l}\text { Alm (1984) } \\
\text { Needham et al. }\end{array}$ & Minnesota & 60 & 35 & NR & 5 \\
\hline $\begin{array}{l}\text { (1991) } \\
\text { Anaka, D. (1990) }\end{array}$ & $\begin{array}{l}\text { Alberta } \\
\text { British }\end{array}$ & 50 & 46 & 4 & 18 \\
\hline & Columbia & 62 & 26 & 5.3 & 17 \\
\hline $\begin{array}{l}\text { Winsor (1990) } \\
\text { Ishler and }\end{array}$ & Newfoundland & 57 & 33 & 5 & 9 \\
\hline Herrmann (1988) & Pennsylvania & 39 & 35 & NR & 26 \\
\hline
\end{tabular}

$\overline{{ }^{4} \text { Percentages listed will exceed } 100 \% \text { because of multiple responses to the }}$ same question. reasons previously listed and because of the ease of disposal, or the fact they would be away for the holidays. Artificial trees require less maintenance than natural trees, hence these trees can be left unattended once they have been set up. We determined most respondents had used an artificial tree for an average of 10 seasons, and the same tree an average of 8 seasons.

Respondents in households that purchased natural trees indicated that they chose to display a natural tree because (in order of importance): (1) "tradition", (2) "just wanted a real tree", (3) "fragrance", (4) "dislike of artificial trees, and (5) "natural trees are biodegradable". Additionally, over $68 \%$ indicated they have always used a natural tree, and almost $21 \%$ replied they returned to using a natural tree after trying an artificial tree.

The typical natural Christmas tree displayed in Alberta during the 1990 holiday season, retailed on average for $\$ 20.15$, and was just over 6 feet tall. The tree was most often purchased by the senior male member of the family or by several family members. This same person (or these same persons) often purchase the tree every year. It would appear tradition plays an important role in Christmas celebrations. Also, more than $85 \%$ of the trees were purchased, rather than cut or obtained as a gift, and almost half of these trees were purchased at a commercial seasonal lot. Further, nearly $25 \%$ were purchased from seasonal lots operated by charitable organizations or service clubs. The person(s) purchasing the tree most often shopped at only one outlet, only occasionally looking at two or more lots and rarely making more than 3 stops in search of the "perfect tree". Most purchases were made on the weekends closest to the mid-December payday but sales are significant throughout the three weeks prior to December 24.

Over $95 \%$ of the consumers we surveyed were satisfied with the retail service they received from natural tree outlets they purchased from. Most dissatisfaction was commonly related to product quality. Also, most consumers (44\%) thought the trees they purchased were grown in Alberta. Many thought their tree came from British Columbia, Canada (41\%) when in reality most were imported from the United States. Not surprisingly, many consumers $(81 \%)$ responded they would prefer to buy a good quality Alberta grown tree if it was available.

Most purchasers looked for the following characteristics (in order of importance) in a "good" Christmas tree: shape, fullness, height, freshness, straight stem, good price, particular species or shade of green and fragrance. Most (91\%) were satisfied with their purchases but those who were dissatisfied were disappointed that (in order of frequency of complaints): (1) "needles fell off too early", (2) "clean-up was too troublesome", (3) "no tree bag was provided for ease of handling", (4) "tree looked better on the lot than when displayed", (5) "difficulty in setting up the tree" or (6) "the tree was too expensive".

Households that did not display trees had the highest education, the fewest children and interestingly enough the lowest mean annual income. The individuals generally lived in "low rise" $(23 \%)$ or "high rise" $(11 \%)$ apartments, which is twice the average for the population and 3-4 times that for tree purchasers. Only $51 \%$ of these types of individuals lived in detached houses as compared to $74 \%$ or $79 \%$ for individuals that displayed artificial or natural trees, respectively.

In an attempt to ascertain the relative dangers associated with displaying Christmas trees, we asked respondents to identify problems they have experienced related to their use of trees. 
Over $98 \%$ of the respondents ( $n=501$ ) had no problems with their artificial trees. Those that did identified such problems as: "smoke or fire" ( $n=2)$, "melting plastic due to overheating by lights" $(n=2)$, "pets knocking over tree" $(n=2)$ and "children knocking over trees" $(n=2)$. Problems associated with natural trees included: "smoke or fire" $(n=2)$, "tree fell over" $(n=10)$, "rash from needles" $(n=1)$, "stepped on needles" $(n=2)$ and "other injuries" $(n=2)$, where the total sample size was 592. In general, respondents had fewer fire related problems with natural trees than with artificial trees.

\section{(b) Commercial and Institutional Consumers}

The variability in characteristics amongst commercial or institutional consumers was much greater than among households. Therefore, it is not as easy to describe a typical commercial or institutional consumer as it is a typical household consumer. Based on the questionnaires returned, we determined the largest component within this sample segment was best classified as providers of supply and services (45\%), while the only other significant group was retailers, who comprised nearly $22 \%$ of the sample respondents. In the category of institutions, schools $(5.5 \%)$ and clinics $(3.2 \%)$ were the two most frequent respondents to our survey. The frequency with which these and other commercial and institutional consumers purchased trees is summarized in Table 2.

Just over half of the respondents indicated that they displayed an artificial Christmas tree. Only $11 \%$ indicated that they displayed a natural tree, while $38 \%$ of the respondents did not display a tree. Not surprisingly, the retail and service industries, followed by industry, schools and manufacturing, were the largest commercial consumers of both natural and artificial trees.

The important reasons given for not displaying a tree are: the building is too small and that displaying a tree is too much trouble. Most respondents (54\%) who did not display a tree in 1990 indicated that they never had displayed a tree, and 64\% indicated that they never would. Those who had displayed a tree in previous years indicated that it had been 3 or 4 years on average since they had displayed a tree.

Of those establishments that did display a tree, more than $80 \%$ indicated that it was an artificial tree and over one-third had switched from displaying a natural tree previously. Once again, the main reasons given were that a natural tree was too troublesome or difficult to set up. Close to $13 \%$, did indicate that they would switch to a natural tree if a "good quality Alberta grown", Christmas tree was available.

The reasons given by this category of consumers for displaying a natural tree are varied; ranging from "just wanting a natural tree for their customers' and staff's enjoyment" to "appre-

Table 2. Frequency of commercial or institutional consumer types that displayed natural or artificial Christmas trees during the 1990 holiday season.

\begin{tabular}{lcr}
\hline Consumer Type & $\begin{array}{c}\text { Number who } \\
\text { displayed tree }\end{array}$ & Percent \\
\hline Services & 49 & 43.3 \\
Retailers & 21 & 18.6 \\
Industry & 10 & 8.8 \\
Schools & 9 & 8.0 \\
Manufacturing & 6 & 5.3 \\
Clinics & 5 & 4.4 \\
Other & 13 & 11.5 \\
Total & 113 & 100.0 \\
\hline
\end{tabular}

ciating that it was biodegradable". The most important reason, though was the fragrant nature of a natural tree. The average price paid for these trees was $\$ 14.24$ for a 7 -foot tree, which is considerably less than that paid by household consumers. These trees were purchased earlier ( $43 \%$ in mid to late November) when compared to household purchases, and most of these trees were purchased by the boss or manager (52\%).

\section{(c) Retailers}

The Christmas tree retail market is dominated by small outlets; many owned by one of several families that dominate the market. This is particularly true in Edmonton and Calgary, the two largest cities in Alberta (estimated population approximately 2 million people), but was also evident in some of the smaller population centers. Some service clubs, such as the Boy Scouts, and some wholesalers have multiple outlets that operate on a co-operative or franchise basis. In addition, several large retailers such as grocery stores offer Christmas trees as loss-leaders.

Each type of group has concerns about the others. The service clubs and charitable organizations are very concerned about both the commercial retailers, who allegedly misrepresent themselves as service clubs or charitable organizations; and the large retail chain stores that under-cut the rest of the tree retailers just to attract customers. The independent owneroperator retailers are also concerned about undercutting by large chains but also have concerns about the 'fly-by-night' operators who flood the market with poor quality trees thus creating an excess of inferior inventory.

There are also concerns about market concentration. For example, one family in Edmonton owns 26 outlets. These family monopolists have their own concerns as well. They are particularly concerned about thievery from employees and competition from large chains that are using Christmas trees as to draw customers. All retailers who had been in the business for some time were most interested in maintaining a source of good quality trees.

A great many retailers have a genuine interest in improving the market situation and many are in favor of supporting Alberta tree growers. Many (64\%) said they would join a co-operative, such as our proposed Christmas Tree Retailers and Wholesalers Association if it existed. Many showed a keen interest in this study and requested a copy of our report when it became available.

There are a number of common characteristics among the typical, natural Christmas tree retail outlets in Alberta. Most are situated along busy thoroughfares, all have available parking, heated office space (usually a trailer, shack or motor home), signs and attractive lighting. All have the capability to operate after dark. The average owner in Alberta has been in business for 8 years.

Operating cost varied considerably between outlets. Service clubs and charitable organizations operate almost at zero cost. They often own their own lot or use a donated lot, and they rely on volunteer labor. They also rely heavily on 'word-of-mouth' or repeat customers rather than extensive signs or other forms of advertising. Most retailers are open an average of 80 hours per week. The other commercial retailers pay up to $\$ 6,000$. for a one month lease, which includes utilities and license fees, and up to $\$ 3,000 /$ month for advertisement. On average, they employ 2-3 people for this 12-23 day season, and their average site lease, city license and utility costs in 1990 dollars amounted to $\$ 1,400 /$ month and their mean advertising costs were close to $\$ 500$ (usually for signage). 
Retailers also marketed a number of other items at their outlets, including tree stands, tree bags, boughs, wreaths, cones, ornaments, tree lights and even artificial trees on occasion. Most retailers seemed to understand the nature of their market niche. Only $28 \%$ indicated that they thought artificial trees were harmful to their business. Nearly half $(47 \%)$ offer free gifts or coupons to their customers; most by offering future discounts, intended to bring the customer back next season. Most offered advice on tree maintenance, set-up and safety, but rarely was this advice in written form.

Most retailers were reluctant to divulge information pertaining to the number and retail prices paid for each tree species sold. This was particularly true of those retailers not associated with service clubs or charitable organizations. There was a great divergence between estimates of the market size using consumer data versus retailer data. Therefore, it was necessary to extrapolate from both sources with evident biases in response from each party in mind (see footnote for Table 3). From such extrapolations, the market size was estimated to be about 300,000 trees, which are valued at $\$ 3,000,000$ at the wholesale level and \$7,000,000 at the retail level. Since most trees sold in the Province are imported and certainly almost all of the expensive trees are imported, we estimate that nearly $\$ 2,600,000$ left the province for the purchase of wholesale Christmas tree, which were used in Alberta during the 1990 holiday season. The estimates of volumes and values by species are presented in Table 3.
When retailers were asked about market trends, they indicated that the demand for most species was increasing, rather than decreasing; with one exception "wild spruce". We can not be sure what species they were referring to because many retailers and purchasers could not accurately identify trees but we believe they were referring to the white spruce (Picea glauca [Moench] Voss) or black spruce (P. mariana [Mill.] B.S.P.), both of which grow wild in Alberta. Furthermore, most indicated the demand for the more expensive trees such as sheared Scots pine (Pinus sylvestris L.), sheared fir (generally Abies grandis [Dougl.] Lindl.) and balsam fir (A. balsamea [L.] Mill.) was increasing rather than remaining constant.

\section{(d) Wholesalers}

We identified at least 32 Christmas tree wholesalers (these were either Growers or Buyer/Seller Brokers) as part of this study (Needham et al. 1991). This information came from tags affixed to the trees or from information provided by the retailers. Although some of the information needed to contact these suppliers was often missing, we do know that trees were shipped to Alberta from as far away as the state of North Carolina, USA; and that firms in many of the western states and the province of British Columbia, Canada also shipped trees to Alberta for the 1990 holiday season.

We solicited information pertaining to prices for the trees sold in Alberta from 11 of these wholesalers but only four supplied useful data. From these data, we determined price ranges,

\begin{tabular}{|c|c|c|c|c|}
\hline Species & $\begin{array}{c}\text { Minimum } \\
\text { number }\end{array}$ & $\underset{\text { number }^{2}}{\text { Maximum }}$ & $\begin{array}{c}\text { Est. or Actual } \\
\text { wholesale } \\
\text { price/foot }\end{array}$ & $\begin{array}{l}\text { Est. retail } \\
\text { price/foot }\end{array}$ \\
\hline BC Fir & 53,944 & 74,818 & 0.87 & 3.00 \\
\hline Douglas-fir & $36,742^{4}$ & 56,651 & 0.71 & 3.12 \\
\hline Total & 90,686 & 131,469 & Mean $(0.79)$ & Mean (3.06) \\
\hline 'Sheared' fir & 87,749 & 12,620 & 2.21 & 4.24 \\
\hline Grand fir & 4,628 & 4,858 & 3.05 & 7.56 \\
\hline Noble fir & 1,698 & 2,209 & 3.58 & 9.22 \\
\hline Balsam fir & & 2,679 & & \\
\hline Total & 15,075 & 22,366 & Mean (2.95) & Mean (7.01) \\
\hline 'Wild' spruce & 45,561 & 76,090 & 1.00 & 4.23 \\
\hline White spruce & & 2,144 & & $3.33^{5}$ \\
\hline Blue/black spruce & 780 & 18,974 & 3.13 & 6.27 \\
\hline Total & 46,341 & 97,208 & Mean (2.07) & Mean (4.61) \\
\hline Jack pine & 310 & 4,935 & 1.25 & 2.46 \\
\hline White pine & 1,945 & 33,180 & 3.31 & 6.66 \\
\hline Lodgepole pine & 3,828 & 7,039 & 1.02 & 2.17 \\
\hline Total & 6,083 & 45,154 & Mean (1.86) & Mean (3.76) \\
\hline Scots pine & $60,829^{4}$ & 60,956 & 2.82 & 6.06 \\
\hline Total All species & 219,014 & 357,153 & & \\
\hline
\end{tabular}

\footnotetext{
${ }^{1}$ Retail estimates scaled up by $25 \%$, consumers scaled down by $15 \%$ to conform with assumptions made in market demand section.

${ }^{2}$ Known estimate plus share of unknown species (share $=$ retail share estimate).

${ }^{3}$ Weighted average of 2 retail average and 1 consumer average.

${ }^{4}$ Consumer estimate is lower and retail estimate is higher.

${ }^{5}$ No retail estimate available.
} 
which were generally less than values provided by retailers. However, differences were generally less than one standard deviation in magnitude. Our efforts in obtaining these data were further complicated by the fact that only a few wholesalers are operating in Alberta. This domination by a few wholesalers significantly complicates the entry into this market place by a new wholesale competitor.

\section{Discussion}

The results of our study are quite comparable to those previously published, especially those of View West Marketing (1990) who also sampled a limited number of locations in Alberta as part of their study. Many of the differences among our results and those of others appear to be due to the wording used in asking the original questions. Location of sampling also affected the comparability of results. For example, we determined annual income of households that purchased natural trees was between $\$ 40,000$ and $\$ 69,000$, whereas Winsor (1990) found the mean annual income for the Newfoundland study to be $>$ $\$ 60,000$. Nevertheless, in both studies natural trees were most often selected by households in the highest income bracket.

In general traditions play an important role in how people participate in Christmas-related activities. Also, the presence of children greatly influence what decisions are made during this season. As in other studies, most people buy natural trees because they smell good and are seen as the "real" Christmas tree. Reasons for not buying a natural tree basically revolve around mess and ease of displaying the tree as well as the length of time individual trees will be displayed. Space is also a limiting factor.

Although not specifically determined by this study, we believe there is a desire by many homeowners to display a Christmas tree for a longer period of time. We suspect many would like to display a tree for most of December if possible. This was certainly true for most commercial or institutional purchasers, who generally purchased their trees during the last week in November. If this is true, we suspect this could significantly affect the marketing of natural trees.

The cost of a Christmas tree had little influence on an individual's decisions to display a tree or on which type of tree to buy. Generally, people who do not buy a tree will not buy a tree even if tree prices were reduced by $5-20 \%$. Perhaps we should have used higher percentages in our attempts to uncover levels of compensation required to induce people to buy a tree but we did not. Also, when consumers were asked to list why they did not display a natural tree, they ranked the "price of the tree" as sixth on their list. As for artificial tree buyers, cost considerations ranked fifth on their list. Therefore, although costs must be considered by consumers it is not the most important factor when making the decision to buy or not to buy a Christmas tree.

Some might conclude that Christmas tree safety was a concern in the population we surveyed. Over $94 \%$ of the respondents said they watered their trees regularly but, interestingly, only $5 \%$ of the respondents actually selected trees that they knew had been sprayed with a fire retardant chemical. Over 52\% of our respondents, purchase trees that they knew had not been coated with a retardant. Although there seems to be little value in buying a tree sprayed with a fire suppressant (View West Marketing 1990), this mixed message contributes little to our understanding of how seriously natural or artificial
Christmas tree users approach fire safety and tree use.

It is interesting to note that fire related problems are not common in either type of tree (artificial ([0.4\%] or natural $0.34 \%]$ ). The actual occurrence of smoke or fire in either type of tree may even be less than determined here because we do not know how many years individual respondents had displayed trees. If respondents displayed trees for only two years then these percentages would be half those presented. Also, we could not test for significant differences in these results due to lack of data. Nevertheless, it would appear that smoke or fires are not a significant problem in trees displayed in Alberta during the 1990 holiday season.

Market domination in Alberta by a few retailers who have been selling Christmas trees for a number of years suggests some people consider this business as profitable. Of course the profitability of a tree outlet varies considerably due to the cost of renting space, the availability of qualified, yet low cost, employees and the hours of operation. Outlets that rely on donated space and volunteer labor tend to be extremely profitable. Product diversification such as wreaths, tree stands, decorations and the sale of boughs are frequently being used to make commercial lots more profitable. We found it interesting that no lots sold smaller (table size) for display, particularly in light of the fact that some households display more than one tree.

\section{Marketing Recommendations}

Household consumers have a few concerns about displaying natural Christmas trees. The mess associated with a natural tree and the difficulty of setting up such a tree are very significant factors in the decisions made. For the marketing of natural Christmas trees to reach its potential, the trees will have to be fresh and well shaped. In addition the product will have to become more convenient to display and maintain. It is evident that there are several steps that can be taken in order to achieve these goals. These are: (1) bagging or the wrapping of the tree at the tree lot, which will reduce the mess associated with shipping and handling, (2) the development and marketing of an easy to use tree stand, which should have a large water reservoir and (3) the promotion of an Alberta grown product, which is uniform and of the highest quality. In addition, a coordinated effort to show the public just how safe and environmentally friendly a natural Christmas tree is in relation to its artificial counterpart, would likely prove valuable.

\section{Acknowledgments}

We gratefully acknowledge the financial and technical support provided by individuals in the Forestry Industry Development Division of the Alberta Forestry Lands and Wildlife Ministry for the Province of Alberta, especially Mr. Al Brennan who was the Director of that Division. A special thanks is extended to Mrs. D. Needham for volunteering to open, sort, count, and number the returned questionnaires. The constructive review provided by Mr. Bill Hamilton, a Christmas tree specialist with the Province of New Brunswick, significantly improved our manuscript and we are grateful. Lastly, we acknowledge the large number of individuals who graciously responded to our survey. Without their time and openness this study would not have been possible. 


\section{References}

Alm, A.A. 1984. Artificial vs. natural trees in Minnesota. Am. Christmas Tree J. 28(3): 55-56.

Anaka, D. 1990. "The real Christmas tree" consumer survey. An unpublished report on file British Columbia Ministry of Agriculture and Fisheries, Victoria, BC Canada.

Brummel, J.S. 1965. An analysis of Christmas tree market in Kansas. M.S. thesis, Kansas State Univ., Manhattan.

Chafin, D.G. 1988. Consumer practices, attitudes about Christmas tree purchases. Christmas Trees 16(1): 30-32.

Gwinner, M. 1987. How would you spend half-million? Christmas Trees 15(4): 24-27.

Hildebrandt, R. 1991. Marketing Christmas trees: implications of a Kansas study. J. For. 89: 33-37.

Hildebrandt, R., W.L. Loucks, and D.B. Erickson. 1989. Marketing Christmas trees in Kansas: consumers' purchasing habits. Rep. Progr. 579, K.S.U. Contrib. 90-121-S Agric. Exp. Stn., Kansas State Univ., Manhattan.
Hu, S.C., and P.Y. Burns. 1981. Christmas tree marketing studies in the Baton Rouge area. LSU For. Note 132, Agric. Exp. Stn., Louisiana State Univ., Baton Rouge.

Ishler, A.S., and R.O. Herrmann. 1988. Marketing Pennsylvaniagrown Christmas trees. Christmas Trees 16(3): 22-30.

Needham, D., W. Phillips, P. Woodard, and L. Constantino. 1991. Growing Christmas trees in Alberta - a market analysis and feasibility study. Proj. Rep. No. 91-08. Dep. Rural Economy, Univ. Alberta, Edmonton.

View West Marketing. 1990. A Christmas tree marketing study. A report prepared for the Canada-British Columbia Agric.-Food Regional Development Subsidiary Agreement (ARDSA 1985-1990) available from West View Marketing, 3367 Wishart Rd., Victoria, B.C., Canada. V9C 1R6.

Winsor, J.E. 1990. A marketing research study on the Christmas tree market of St. John's and the surrounding areas. For. Can. Infor. Rep. N-X-276.

\section{Change of Address}

Date Section

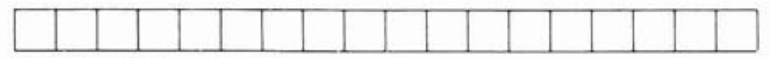

Surname first - no titles

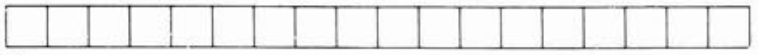

Street

City and Province

Postal Code

\section{Changement d'adresse}

Date Section

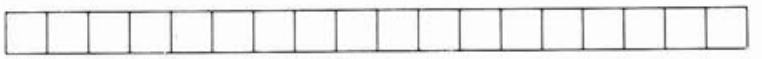

Prénom en avant - pas de titres

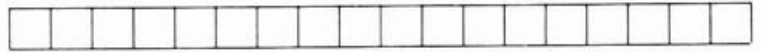

Rue

Ville et Province

Code Postale 